Wafi, et al/Jurnal Ekonomi Syariah Teori dan Terapan Vol. 6 No. 7 Juli 2019: 1494-1508; PEMBERIAN ZAKAT PRODUKTIF UNTUK KINERJA MODAL USAH DAN KESEJAHTERAAN EKONOMI MUSTAHIK PADA LEMBAGA AMIL ZAKAT NASIONAL NURUL HAYAT DI BOJONEGORO

\title{
PEMBERIAN ZAKAT PRODUKTIF UNTUK KINERJA MODAL USAH DAN KESEJAHTERAAN EKONOMI MUSTAHIK PADA LEMBAGA AMIL ZAKAT NASIONAL NURUL HAYAT DI BOJONEGORO ${ }^{1}$
}

\author{
Luthfan Hibatul Wafi \\ Departemen Ekonomi Syariah- Fakultas Ekonomi dan Bisnis-Universitas Airlangga \\ Email: Luthfan.hibatul-13@feb.unair.ac.id \\ Sri Herianingrum \\ Departemen Ekonomi Syariah- Fakultas Ekonomi dan Bisnis-Universitas Airlangga \\ Email: Sri.herianingrum@feb.unair.ac.id
}

\begin{abstract}
:
This research aims to find out and analyze the influence of productive zakat to mustahiq's business performance and economic welfare at National Amil Zakat Institution Nurul Hayat in Bojonegoro. LAZNAS Nurul Hayat Bojonegoro is one of amil zakat institutions that can develop programs in managing the largest zakat in Bojonegoro. Population in this research is all mustahiqs who received zakat from Amil Zakat Institution Nurul Hayat Bojonegoro. Sampling technique used is non-probability sampling by using purposive sampling method. There are 156 mustahik obtained that received productive zakat.The type of data used is primary data, while data collection method is questionnaire.
\end{abstract}

Keywords: productive zakat, mustahiq'sbusiness performance, mustahiq's economic welfare.

\section{PENDAHULUAN}

Kemiskinan merupakan salah satumasalah sosial bagi bangsa dan merupakan masalah besar yang dapat mempengaruhi akidah umat beragama. Salah satu penyebab orang keluar dari agama ialah kemiskinan dan kefakiran. Kemiskinan merupakan hal yang kompleks karena menyangkut beberapa aspek seperti tidak terpenuhinya sandang, pangan, pendidikan, kesehatan, pekerjaan dan sebagainya.Masalah kemiskinan muncul karena adanya keterbatasan dari sekelompok anggota masyarakat yang secara struktural tidak memiliki peluang dan kemampuan yang memadai untuk mencapai tingkat kehidupan yang lebih layak. Akibatnya,mereka harus mengakui keunggulan kelompok masyarakat lain dalam persaingan untuk mencari nafkah dan pemilikan aset produksi. Persaingan yang tidak seimbang ini membuat para sekelompok masyarakat yang tidak unggul kian lama semakin merasa tertinggal. Dalam prosesnya gejala ini menimbulkan persoalan ketimpangan distribusi pendapatan, dan selanjutnya kesenjangan kesejahteraan.

Di Indonesia, kemiskinan sudah terjadi sejak zaman dahulu dimana pemerintah Indonesia tidak dapat menekan angka kemiskinan dari tahun ke tahun dan mengurangi angka kemiskinan merupakan pekerjaan yang serius untuk pemerintah kita. Berbagai upaya telah dilakukan pemerintah untuk mengatasi permasalahan kemiskinan. Dalam Kajian

\footnotetext{
${ }^{1}$ Jurnal ini merupakan bagian dari skripsi Luthfan Hibatul Wafi, NIM: 041300433150, yang diuji pada tanggal 6 Mei 2019.
} 
Wafi, et al/Jurnal Ekonomi Syariah Teori dan Terapan Vol. 6 No. 7 Juli 2019: 1494-1508; PEMBERIAN ZAKAT PRODUKTIF UNTUK KINERJA MODAL USAH DAN KESEJAHTERAAN EKONOMI MUSTAHIK PADA LEMBAGA AMIL ZAKAT NASIONAL NURUL HAYAT DI BOJONEGORO

Kebijakan Penguatan Peran Pemerintah Daerah Dalam Percepatan Pengentasan Kemiskinan oleh Kementerian Sekretariat Negara (2015) dijelaskan bahwa strategi pemerintah difokuskan pada tiga klaster, yaitu program bantuan dan perlindungan sosial terpadu berbasis keluarga, program penanggulangan kemiskinan berbasis pemberdayaan masyarakat, dan program penanggulangan kemiskinan berbasis pemberdayaan usaha ekonomi mikro dan kecil (UMK). Dari hasil sensus penduduk yang dilakukan BPS pada tahun 2015 sampai dengan 2018 ditemukan jumlah penduduk miskin dalam juta orang dan prosentasenya, ditunjukkan pada gambar 1 sebagai berikut.

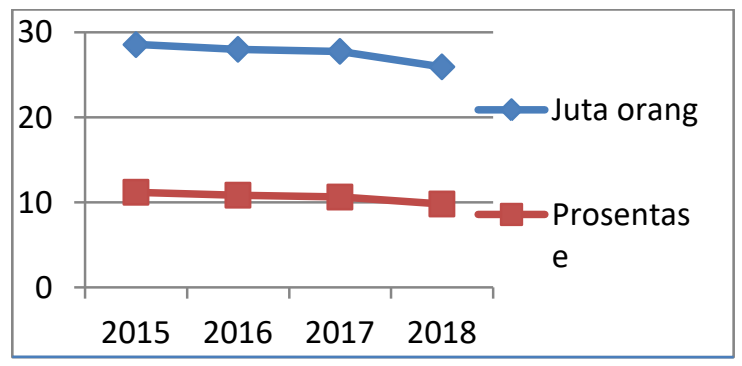

Gambar 1.

Data Kemiskinan di Indonesia

Tahun 2015 - 2018

Sumber: Data finance.detik.com yang diolah peneliti, 2019

Dari data tersebut diketahui bahwa pada tahun 2015 jumlah orang miskin di Indonesia ialah 28,59 juta atau 11,22\%, tahun 2016 penduduk miskin tercatat 28,01 juta atau 10,86\%, kemudian tahun 2017 penduduk miskin tercatat 27,77 juta atau 10,64\%, dan tahun 2018 jumlah penduduk miskin tercatat 25,95 juta orang atau $9,82 \%$. Data tersebut menunjukkan jumlah kemiskinan pada 4 tahun terakhir dengan hasil jumlah penduduk miskin setiap tahunnya menurun. Hal tersebut mendukung adanya bantuan sosial tunai dari pemerintah yang tumbuh 87,6 persen pada kuartal I 2018 atau lebih tinggi dibanding kuartal I 2017 yang hanya tumbuh 3,39 persen (Putera, 2018). Kegiatan bantuan sosial tersebut mencerminkan kesuksesan program pemerintah dalam mengentaskan kemiskinan melalui yayasan atau lembaga berbadan hukum. Yayasan atau lembaga berbadan hukum yang mempunyai program pengentasan kemiskinan yang dikelola oleh umat islam salah satunya adalah Lembaga Amil Zakat (LAZ). LAZ merupakan yayasan yang dikelola umat islam untuk membentuk program sosial terutama pengelolaan zakat.

Ditinjau dari segi bahasa, kata zakat mempunyai beberapa arti yaitu keberkahan, pertumbuhandan perkembangan, kesucian serta keberesan. Sedangkan secara istilah zakat adalah bagian dari harta dengan persyaratan tertentu, yang Allah SWT mewajibkan kepada pemiliknya untuk diserahkan kepada yang berhak menerimanya, dengan persyaratan tertentu pula. Dalam Al-Qur'an seringkali kata zakat digabung dengan kata shalat (Muhammad, 2002).Asnaini (2008) menjelaskan bahwa pemanfaatan zakat dapat digolongkan ke dalam empat kategori, yakni zakat konsumtif tradisional, zakat konsumtif kreatif, zakat produktif tradisional, dan 
Wafi, et al/Jurnal Ekonomi Syariah Teori dan Terapan Vol. 6 No. 7 Juli 2019: 1494-1508; PEMBERIAN ZAKAT PRODUKTIF UNTUK KINERJA MODAL USAH DAN KESEJAHTERAAN EKONOMI MUSTAHIK PADA LEMBAGA AMIL ZAKAT NASIONAL NURUL HAYAT DI BOJONEGORO

zakat produktif kreatif. Zakat konsumtif tradisional adalah zakat dibagikan untuk dimanfaatkan langsung (zakat fitrah), zakat konsumtif kreatif adalah zakat yang diwujudkan dalam bentuk lain dari barangnya semula seperti diwujudkan dalam bentuk alat-alat sekolah dan beasiswa, zakat produktif tradisional adalah zakat diberikan dalam bentuk barang-barang yang produktif (hewan ternak, mesin jahit, alat-alat pertukangan, dan sebagainya), sedangkan zakat produktif kreatif adalah zakat diwujudkan dalam bentuk pemodalan baik untuk membangun proyek sosial atau menambah modal pedagang pengusaha kecil. Menurut Teten Kustiawan, cara penyaluran zakat dapat dilakukan dengan cara menyalurkan zakat konsumtif dan zakat produktif sesuai dengan komposisi kebutuhan masyarakat. Menurut Didin (dalam Maulana), zakat produktif lebih diutamakan untuk usaha yang bersifat produktif guna meningkatkan kesejahteraan ekonomi masyarakat.

Penelitian yang dilakukan oleh Rusli (2013) pemberian zakat produktif yang efektif dalam bentuk modal usaha berpengaruh dalam meningkatkan pendapatan masyarakat penerima zakat produktif, dimana terjadi perbedaan pendapatan sebelum menerima dan sesudah menerima modal zakat produktif. Hal tersebut juga dilakukan oleh Karimah (2017) yang menjelaskan bahwa efektivitas zakat produktif yang telah disalurkan untuk bantuan modal usaha para mustahik, dapat mendorong kesejahteraan ekonomi para mustahik.

Pendayagunaan dana zakat secara produktif merupakan sebuah strategi yang tepat dalam menanggulangi kemiskinan. Namun harus pula didukung dengan tenaga pendamping dan pengawas oleh Badan Amil Zakat di lapangan, supaya mustahik lebih bersemangat dalam berusaha. Oleh karena itu, Badan Amil Zakat Nasional Nurul Hayat Bojonegoro memiliki peran yang sangat penting dalam mengoptimalisasi manfaat pendayagunaan dana zakat, khususnya dana zakat produktif sehingga dapat meningkatkan kinerja usaha kecil mustahik. Sehingga adanya pemberian zakat produktif yang tanpa bunga maka pengusaha kecil menengah ini merasa terbantu dan bisa mengembangkan usahanya supaya lebih berdaya.

Penelitian yang dilakukan oleh Mahmudah dan Ghoniyah (2016) sebagian besar mustahik merasa pembiayaan zakat produktif sebagai media yang dapat membantu pemberdayaan usaha kecil menengah yang mereka jalankan.Nurbismi dan Ramsli (2018) menyatakan bahwa zakat produktif dalam mereduksi kemiskinan belum secara menyeluruh terkoordinir dalam mengupayakan penurunan kemiskinan. Hal tersebut juga sejalan dengan penelitian yang dilakukan Nidityo dan Laila (2014) zakat produktif yang disalurkan oleh BAZNAS Jatim memiliki peranan dalam meningkatkan kinerja produksi mustahik, dikarenakan zakat 
Wafi, et al/Jurnal Ekonomi Syariah Teori dan Terapan Vol. 6 No. 7 Juli 2019: 1494-1508; PEMBERIAN ZAKAT PRODUKTIF UNTUK KINERJA MODAL USAH DAN KESEJAHTERAAN EKONOMI MUSTAHIK PADA LEMBAGA AMIL ZAKAT NASIONAL NURUL HAYAT DI BOJONEGORO

produktif yang disalurkan dalam bentuk modal usaha kepada mustahik dapat meningkatkan indikator-indikator kinerja yang telah ditentukan.

Berdasarkan pada pemikiran dan latar belakang masalah diatas, maka penulis tertarik mengadakan penelitian dengan judul "Pengaruh zakat produktif terhadap kinerja usaha mustahik dan kesejahteraan ekonomi mustahik pada LembagaAmil Zakat Nasional Nurul Hayat Kabupaten Bojonegoro".

\section{Rumusan Masalah}

Dalam penyusunan penulisan proposal skripsi ini, penulis mencoba merumuskan, membahas, mengemukakan dan mengajukan hal-hal yang berkaitan erat dengan latar belakang masalah. Berdasarkan latar belakang masalah tersebut, maka dapat diambil rumusan masalah sebagai berikut:

1. Apakah zakat produktif berpengaruhterhadap kinerja usaha mustahik?

2. Apakah zakat produktif berpengaruh terhadapkesejahteraan ekonomi mustahik?

3. Apakah kinerja usaha mustahikberpengaruh terhadap kesejahteraan ekonomi mustahik?

\section{Tujuan Penelitian}

Sejalan dengan rumusan masalah tersebut, maka tujuan penelitian ini adalah:

1. Untuk mengetahui dan menganalisis pengaruh zakat produktif terhadap kinerjausahamustahik di LAZ Nurul Hayat Kabupaten Bojonegoro.
2. Untuk mengetahui dan menganalisis pengaruh zakat produktif terhadap kesejahteraan ekonomi mustahik di LAZ Nurul Hayat Kabupaten Bojonegoro.

3. Untuk mengetahui dan menganalisis pengaruh kinerja usaha mustahik terhadap kesejahteraan ekonomi mustahik di LAZ Nurul Hayat Kabupaten Bojonegoro.

\section{LANDASAN TEORI}

Keberadaan zakat ada sejak zaman Rasulullah SAW yang diteruskan oleh para sahabat nabi, tabi'in, tabi'uttabi'in dan generasi penerus lainnya sampai sekarang.Zakat ditinjau dari segi bahasa berasal dari kata dasar zakaa yang berarti suci, berkah, tumbuh dan terpuji, sedangkan dari segi istilah fiqih berarti sejumlah harta tertentu yang diwajibkan Allah SWT yang diserahkan kepada orang-orang yang berhak menurut-Nya (Muhammad, 2002). Wahid, dkk (2009) menjelaskan zakat merupakan salah satu rukun Islam yang berperan penting dalam kehidupan umat Islam, berupa mekanisme ibadah dan perekonomian antara matlamatnya membersihkan jiwa manusia serta hartanya (pembayar zakat) dan membantu golongan yang kurang berkemampuan (asnaf) kerana kemungkinan terdapat hak orang lain dalam proses memperoleh harta tersebut. Tho'in (2017) mengungkapkan zakat merupakan kewajiban umat Islam untuk menyerahkan sejumlah harta tertentu sesuai dengan syariat agama 
Wafi, et al/Jurnal Ekonomi Syariah Teori dan Terapan Vol. 6 No. 7 Juli 2019: 1494-1508; PEMBERIAN ZAKAT PRODUKTIF UNTUK KINERJA MODAL USAH DAN KESEJAHTERAAN EKONOMI MUSTAHIK PADA LEMBAGA AMIL ZAKAT NASIONAL NURUL HAYAT DI BOJONEGORO

Islam yang diserahkan kepada orangorang yang berhak menerimanya.

Sudut pandangan Agama Islam, pahala akan bertambah dan harta pun berkembang karena mendapat ridho dari Allah Swt dan berkat doa dari fakir miskin, anak-anak yatim dan para mustahik lainnya yang merasa disantuni dari hasil zakat tersebut. Hal ini sebagaimana firman Allah Swt dalam surat At-Taubah ayat 103 dan surat Ar-Ruum ayat 39 :

Artinya: "Ambillah zakat dari sebagian harta mereka, dengan zakat itu kamu membersihkan dan mensucikan mereka dan mendoalah untuk mereka. Sesungguhnya doa kamu itu (menjadi) ketenteraman jiwa bagi mereka. dan Allah Maha mendengar lagi Maha mengetahui" (QS. At-Taubah:103).

Artinya: "Dan sesuatu Riba (tambahan) yang kamu berikan agar Dia bertambah pada harta manusia, Maka Riba itu tidak menambah pada sisi Allah. dan apa yang kamu berikan berupa zakat yang kamu maksudkan untuk mencapai keridhaan Allah, Maka (yang berbuat demikian) Itulah orang-orang yang melipat gandakan (pahalanya)" (QS. Ar-Ruum: 39).

Menurut M.Quraish Shihab dalam tafsir Al-Mishbah, surat At Taubah ayat 103 dan Surat Ar Rum Ayat 39 diatas menjelaskan bahwa Allah membahas tentang haramnya riba, kemudian Allah membahas tentang masalah ZIS (Zakat, Infaq, dan Shadaqah), Dimana riba' dan zakat adalah sesuatu yang sangat berseberangan dan kontradiktif. Riba' adalah sesuatu yang tidak akan berkembang dan tidak akan memiliki berkah hartanya, sedangkan ZIS adalah sesuatu yang akan berkembang dan memberikan berkah dunia-akhirat. Ayat ZIS disandingkan dengan riba' menjelaskan bahwa ZIS dapat membawa umat manusia keluar dari masalah ekonomi seperti kemiskinan. Sedangkan riba' adalah penyebab adanya kemiskinan dunia-akhirat.

Menurut Syarifuddin (2014), bekerja atau berusaha adalah aktivitas yang direncanakan dan dilakukan dalam setiap tahapan untuk mendapatkan value demi memenuhi kebutuhan hidup serta memberikan manfaat bagi umat mnausia. Bekerja atau berusaha mencerminkan kegiatan yang dilakukan oleh seseorang, baik individu maupun kelompok untuk memproduksi suatu barang atau jasa yang baik dan halal.Afzalurrahman (2000) menyatakan bahwa bekerja menunjukkan tenaga fisik dan pikiran yang dilakukan untuk memperoleh imbalan yang mencakup seluruh bentuk pekerjaan. Berdasarkan pengertian tersebut, disimpulkan bahwa bekerja atau berusaha yang Islami adalah kegiatan untuk melaksanakan suatu aktivitas dengan melibatkan fisik, ilmu pengetahuan dan iman taqwa untuk memproduksi suatu barang dan jasa dengan halal, baik untuk kepentingan individu maupun bagi kelompok.

Purbaya (2016) mendefinisikan kesejahteraan ekonomi merupakan 
Wafi, et al/Jurnal Ekonomi Syariah Teori dan Terapan Vol. 6 No. 7 Juli 2019: 1494-1508; PEMBERIAN ZAKAT PRODUKTIF UNTUK KINERJA MODAL USAH DAN KESEJAHTERAAN EKONOMI MUSTAHIK PADA LEMBAGA AMIL ZAKAT NASIONAL NURUL HAYAT DI BOJONEGORO

cabang ilmu ekonomi yang menggunakan teknik ekonomi mikro untuk menentukan secara serempak efisiensi alokasi dari ekonomi makro dan akibat distribusi pendapatan yang saling berhubungan. Kegiatan ekonomi merupakan kegiatan yang tidakterlepas dari pasar. Pada dasarnya kegiatan ekonomi lebih mementingkan sebuah keuntungan bagi pelaku ekonomi dari pasar tersebut. Sehingga sangat sulit dalam menemukan ekonomi yang dapat mensejahterakan, apabila dilihat dari mekanisme pasar yang ada. Keadaan pasar yang begitukompetitif untuk mencari keuntungan, merupakan salah satuhal yang menjadi penghambat untuk menuju kesejahteraan.

\section{Konsep Kesejahteraan Mustahik}

Zakat merupakan alat bantu sosial mandiri menjadi kewajiban moral bagi orang yang berkecukupan untuk membantu golongan yang membutuhkan. Sehingga zakat dapat menjadi istrumen kesejahteraan mustahiq. Kamus besar bahasa Indonesia kesejahteraan adalah keamanan, keselamatan, ketentraman, dan kesenangan hidup. Sedangkan mustahiq adalah golongan orang yang menerima zakat.Uswatun

kesejahteraan mustahik menggambarkan ketentraman dan kesenangan hidup secara lahir maupun batin yang diterima oleh orang yang berhak menerima zakat.Mutia dan Zahara (2009) menjelaskan kesejahteraan mustahik merupakan pendapatan atas usaha yang dijalankan mustahiq setelah menerima modal zakat produktif.Jadi, kesejahteraan zakat produktif merupakan kepuasan mencukupi kebutuhan hidup mustahiq dalam menjalankan usahanya setelah menerima bantuan zakat produktif.

Menurut Karim (2003) kesejahteraan dari suatu masyarakat tergantung kepada pencarian dan pemeliharaan lima tujuan dasar, yaitu :

1. Agama (Hifdz Ad-Din)

2. Hidup atau jiwa (Hifdz An-Nafs)

3. Keluarga atau keturunan (Hifdz AnNasb)

4. Harta atau kekayaan (Hifdz An-Maal)

5. Intelek atau akal (Hifdz An-Nasl)

III. METODE PENELITIAN

Penelitian ini menggunakan tipe penelitian deskriptif dengan pendekatan kuantitatif. Metode penelitian kuantitatif sebagaimana dikemukakan oleh Sugiyono (2017: 14) diartikan sebagai metode penelitian yang berlandaskan pada filsafat positivism, digunakan untuk meneliti pada populasi atau sampel tertentu dimana teknik pengambilan sampel pada umumnya dilakukan secara random (acak), pengumpulan data menggunakan instrumen penelitian, analisis data bersifat kuantitatif/statistik dan bertujuan untuk menguji hipotesis yang telah ditetapkan. Dalam penelitian kuantitatif, masalah yang dibawah peneliti sudah harus jelas. Menurut Sugiyono (2017: 15), penelitian deskriptif adalah penelitian yang dilakukan untuk mengetahui nilai variabel mandiri, baik satu variabel atau lebih tanpa 
Wafi, et al/Jurnal Ekonomi Syariah Teori dan Terapan Vol. 6 No. 7 Juli 2019: 1494-1508; PEMBERIAN ZAKAT PRODUKTIF UNTUK KINERJA MODAL USAH DAN KESEJAHTERAAN EKONOMI MUSTAHIK PADA LEMBAGA AMIL ZAKAT NASIONAL NURUL HAYAT DI BOJONEGORO

membuat perbandingan, atau menghubungkan dengan variabel lainnya. Berdasarkan teori tersebut, penelitian kuantitatif deskriptif merupakan data yang diperoleh dari sampel populasi penelitian dianalisis sesuai dengan metode statistik yang digunakan. Penelitian kuantitatif deskriptif dalam penelitian ini digunakan untuk menjawab rumusan masalah serta tujuan penelitian yaitu pengaruh zakat produktif terhadap kinerja usaha mustahik dan kesejahteraan ekonomi mustahik pada Lembaga Amil Zakat Nasional Nurul Hayat Kabupaten Bojonegoro.

Subjek yang digunakan pada penelitian ini adalah seluruh mustahik di Lembaga Amil Zakat Nurul Hayat Kabupaten Bojonegoro yang menerima zakat produktif.Data yang digunakan adalah data primer dimana peneliti terjun langsung untuk melakukan observasi.Observasi dilakukan menggunakan metode survey untuk mendistribusikan kuisioner kepada responden.Pengujian seluruh hipotesis dalam penelitian ini menggunakan metode analisis Component Based SEM dengan alat penguji Partical Least Square (PLS) versi 3.0.

Metode analisis Component Based SEM digunakan peneliti karena variabel penelitian ini merupakan penelitian pengembangan dimana variabel tersebut bersifat unobserved dan antar variabel memiliki kausalitas. Penelitian ini menggunakan variabel independen yakni Zakat Produktif $(X)$, sedangkan variabel dependen yang digunakan adalah Kinerja Usaha Mustahik (Y1) dan Kesejahteraan Ekonomi Mustahik (Y2).

Penelitian ini bertujuan untuk melihat pengaruh Zakat Produktif (X) terhadap Kinerja Usaha Mustahik (Y1), Zakat Produktif $(X)$ terhadap Kesejahteraan Ekonomi Mustahik (Y2), dan Kinerja Usaha Mustahik (Y1) terhadap Kesejahteraan Ekonomi Mustahik (Y2)

\section{Jenis Data}

Data yang digunakan adalah data primer.Menurut Abdillah dan Jogiyanto (2015) data primer menunjukkan dimana keaslian informasi bersumber dari pihak utama yang memiliki data tersebut. Dalampenelitian yang akan dilakukan adalah menggunakan jenis penelitian kuantitatif. Menurut Sugiyono (2017), penelitian kuantitatif adalah penelitian yang menggunakan data yang dibentuk dengan angka. Responden penelitian ini merupakan mustahikyang terdaftar sebagai penerima zakat produktif di LAZNAS Nurul Hayat Bojonegoro.

\section{Sumber Data}

Sumber data yang digunakan darikuesioner yang dibuat oleh peneliti kemudian diisi oleh responden.Menurut Sugiyono (2017), kuisioner merupakan teknik pengumpulan data yang dilakukan dengan cara memberiseperangkat pernyataan tertulis kepada responden untuk dijawab.Kuisioner disebar kepada responden sesuai dengan kriteria yang telahdiajukan oleh peneliti.Dalam penelitian ini menggunakan jenis kuisioner 
Wafi, et al/Jurnal Ekonomi Syariah Teori dan Terapan Vol. 6 No. 7 Juli 2019: 1494-1508; PEMBERIAN ZAKAT PRODUKTIF UNTUK KINERJA MODAL USAH DAN KESEJAHTERAAN EKONOMI MUSTAHIK PADA LEMBAGA AMIL ZAKAT NASIONAL NURUL HAYAT DI BOJONEGORO

tertutup, dimana pernyataan peneliti mengarahkan responden untukmenjawab pendapat berdasarkan pilihan jawaban yang disediakan.Metode distribusi kuisioner yang digunakan adalah metode self administered. Metode tersebut merupakan metode dengan distribusilangsung kuisioner kepada responden.

\section{Prosedur pengumpulan data}

Prosedur yang digunakan untuk pengumpulan data pada penelitian ini adalah penelitian lapangan (field research), dimana diambil dengan cara pengamatan pada lapangan terhadap data primer melalui penyebaran kuesioner.

Populasi

Menurut Mauludi

menyatakan bahwa populasi adalah wilayah generalisasi yang mencakup atas semua obyek atau subyek yang mempunyai kuantitas dan karakteristik tertentu yang ditetapkan oleh peneliti yang digunakan sebagai bahan penelitian.Dalam penelitian ini populasi yang digunakan adalah semua mustahik yang terdaftar sebagai penerima zakat produktif di Lembaga Amil Zakat Nurul Hayat Kabupaten Bojonegoro.Jumlah populasi objek sasaran dalam penelitian ini berjumlah 345 mustahik.

\section{Sampel}

Sampel menurut Sugiyono (2017) adalah bagian dari jumlah dan karakteristik yang dimiliki oleh populasi tersebut sampel yang diambil dari populasi tersebut harus dapat mewakili. Ukuran sampel merupakan banyaknya sampel yang akan diambil dari suatu populasi. Penelitian yang diajukan menggunakan teknik sampling yaitu Non Probability Sampling dengan metode Purposive Sampling. Sugiyono (2017), teknik purposive sampling adalah teknik penentuan sampel dengan pertimbangan tertentu. Berdasarkan hal tersebut peneliti mengajukan kriteria sampel dengan pertimbangan adalah mustahik yang menerima bantuan zakat produktif yakni sebanyak 156 responden yang terdiri dari 100 bunda yatim, 32 petani, dan 24 peternak.

\section{Teknik Analisis dan Pengelolaan Data}

Pada penelitian kali ini peneliti menggunakan metode pengumpulan data dengan teknik kuesioner, dimana teknik tersebut dapat dilakukan dengan cara memberi angket yang berisi seperangkat pertanyaan atau pernyataan tertulis yang sifatnya terbuka atau tertutup kepada respondenuntuk dijawabnya (Abdillah dan Jogiyanto, 2016). Kuesioner merupakan daftar pertanyaan terbuka atau tetutup yang di distribusikan kepada responden untuk diisi sehingga hasil isian dari responden merupakan tanggapan dan jawaban atas berbagai pertanyaan yang diajukan dalam arti laporan tentang pribadinya atau hal-hal yang mereka ketahui (Ghozali, 2016). Kuesioner penelitian didistribusikan kepada para mustahik yang menerima dana zakat produktif.

\section{Analisis Structural Equation Modeling (SEM)}

Teknik analisis data yang digunakan dalam penelitian ini adalah structural 
Wafi, et al/Jurnal Ekonomi Syariah Teori dan Terapan Vol. 6 No. 7 Juli 2019: 1494-1508; PEMBERIAN ZAKAT PRODUKTIF UNTUK KINERJA MODAL USAH DAN KESEJAHTERAAN EKONOMI MUSTAHIK PADA LEMBAGA AMIL ZAKAT NASIONAL NURUL HAYAT DI BOJONEGORO

Equation Modeling (SEM).Model persamaan struktural atau Structural Equation Modeling (SEM) merupakan suatu analisis yang menggabungkan pendekatan analisis faktor (factor analysis), model struktural (structural model), dan analisis jalur (path analysis) (Sugiyono, 2014).SEM adalah teknik analisis data digunakan untuk menguji hipotesis yang terstruktur dengan variabel dependen diketahui satu atau dapat lebih dari satu.Dalam SEM harus terdapat hubungan kausalitas dimana hubungan tersebut terdapat struktural berseri dengan menggunakan persamaan regresi sehingga susunan model berupa gambar yang mudah dipahami.Hubungan struktural tersebut diuji dengan statistik secara serempak dalam pengujian hipotesis.Konsep SEM menggunakan prosedur multivariate, dan bersifat confirmatory.

\section{Metode Analisis Partial Least Square (PLS)}

Penelitian ini menggunakan metode analisis Partial Least Square (PLS).Analisis Partial Least Square (PLS) merupakan teknik statistikamultivariat yang melakukan perbandingan antara variabel dependen berganda dan variabel independen berganda. PLS adalah salah satu metode statistika SEM berbasisis varian yang didesain untuk memprediksi sebuah model dengan analisis regresi berganda ketika tejadi permasalahan spesifik pada data, seperti ukuran sampel penelitian kecil, adanya data yang hilang (missing values), dan multikolenearitas.

\section{HASIL DAN PEMBAHASAN}

Hubungan antara zakat produktif terhadap kinerja usaha mustahik

Diketahui bahwa nilai T-Statistic untuk variabel zakat produktifsebesar 5,995 lebih besar dari nilai $\uparrow$ tabel yaitu 1,96 dan nilai signifikansi sebesar $0,000<0,05$. Hal ini menunjukkan bahwa terdapat pengaruh signifikan antara zakat produktif terhadap kinerja usaha mustahik. Nilai T-Statistic lebih besar dari thitungmenunjukkan bahwa terdapat pengaruh antara zakat produktif terhadap kinerja usaha mustahik.Dimana zakat produktif yang diberikan oleh LAZNAS telah mampu meningkatkan produktifitas kinerja usaha yang dijalankan para mustahik.Berdasarkan hal tersebut disimpulkan bahwa Zakat Produktif berpengaruh signifikan terhadap Kinerja Usaha Mustahik, maka $\mathrm{H}_{01}$ ditolak dan $\mathrm{H}_{\mathrm{al}}$ diterima.

\section{Hubungan antara zakat produktif terhadap} kesejahteraan ekonomi mustahik

Diketahui pada tabel 4.15. bahwa nilai T-Statistic untuk variabel zakat produktif sebesar 9,266> 1,96 dan nilai signifikansi $p$ value $0,000<0,05$. Hal ini menunjukkan bahwa terdapat pengaruh yang signifikan antara zakat prduktif terhadap kesejahteraan ekonomi mustahik.Nilai T-Statistic diketahui lebih besar dari $t$ tabel, hal tersebut menunjukkan bahwa terdapat hubungan antara zakat produktif dengan kesejahteraan ekonomi mustahik. Dimana semakin tinggi zakat produktif yang diterima untuk menjalankan usahanya, 
Wafi, et al/Jurnal Ekonomi Syariah Teori dan Terapan Vol. 6 No. 7 Juli 2019: 1494-1508; PEMBERIAN ZAKAT PRODUKTIF UNTUK KINERJA MODAL USAH DAN KESEJAHTERAAN EKONOMI MUSTAHIK PADA LEMBAGA AMIL ZAKAT NASIONAL NURUL HAYAT DI BOJONEGORO

maka menunjukkan bahwa zakat produktif mampu meningkatkan kesejahteraan ekonomi para mustahik .Sehingga dapat disimpulkan bahwa Zakat produktif berpengaruh signifikan Kesejahteraan Ekonomi Mustahik, maka $\mathrm{H}_{02}$ ditolak dan $\mathrm{H}_{\mathrm{a} 2}$ diterima.

Hubungan antara kinerja usaha mustahik terhadap kesejahteraan ekonomi mustahik

Diketahui pada tabel 4.15. bahwa nilai T-Statistic untuk variabel zakat produktif sebesar 8,412> 1,96 dan nilai signifikansi $p$ value $0,000<0,05$. Hal ini menunjukkan bahwa terdapat pengaruh yang signifikan antara kinerja usaha mustahik terhadap kesejahteraan ekonomi mustahik.Nilai T-Statistic diketahui lebih besar dari $t$ tabel, hal tersebut menunjukkan bahwa terdapat hubungan antara kinerja usaha mustahik dengan kesejahteraan ekonomi mustahik.Dimana semakin tinggi produktifitas atas kinerja usaha yang dijalankan mustahik, maka menunjukkan bahwa zakat produktif mampu meningkatkan kesejahteraan ekonomi mustahik dalam mencukupi kebutuhan. Sehingga dapat disimpulkan bahwa Kinerja Usaha Mustahik berpengaruh signifikan Kesejahteraan Ekonomi Mustahik, maka $\mathrm{H}_{03}$ ditolak dan $\mathrm{H}_{\mathrm{a} 3}$ diterima.

\section{Pembahasan}

Pengaruh Zakat Produktif terhadap Kinerja Usaha Mustahik

Berdasarkan hasil penelitian yang telah dilakukan menunjukkan bahwa zakat produktif berpengaruh signifikan terhadap kesejahteraan ekonomi mustahik. Nilai TStatistic untuk variabel zakat produktifsebesar 5,995 lebih besar dari nilai † tabel yaitu 1,968 dan nilai signifikansi sebesar $0,000<0,05$. Hasil ini menunjukkan bahwa semakin besar jumlah zakat produktif yang digunakan mustahik untuk mengembangkan usahanya, maka semakin tinggi kinerja usaha yang dijalankannya.

\section{Pengaruh Zakat Produktif terhadap Kesejahteraan Ekonomi Mustahik}

Berdasarkan hasil penelitian yang telah dilakukan menunjukkan bahwa zakat produktif berpengaruh signifikan terhadap kesejahteraan ekonomi mustahik. Nilai TStatistic untuk variabel zakat produktifsebesar 9,266 lebih besar dari nilai † tabel yaitu 1,968 dan nilai signifikansi sebesar 0,000 < 0,05. Hasil ini menunjukkan bahwa semakin besar peran pemberian zakat produktif maka semakin besar pula pengaruh kesejahteraan ekonomi mustahik. Hal ini sejalan dengan penelitian yang dilakukan Sartika (2008) bahwa besaran dana zakat produktif yang disalurkan mampu meningkatkan pendapatan mustahik.

Pengaruh Kinerja Usaha Mustahik terhadap Kesejahteraan Ekonomi Mustahik

Berdasarkan hasil penelitian yang telah dilakukan menunjukkan bahwa zakat produktif berpengaruh signifikan terhadap kesejahteraan ekonomi mustahik. Nilai TStatistic untuk variabel zakat produktifsebesar 8,412 lebih besar dari nilai † tabel yaitu 1,968 dan nilai signifikansi 
Wafi, et al/Jurnal Ekonomi Syariah Teori dan Terapan Vol. 6 No. 7 Juli 2019: 1494-1508; PEMBERIAN ZAKAT PRODUKTIF UNTUK KINERJA MODAL USAH DAN KESEJAHTERAAN EKONOMI MUSTAHIK PADA LEMBAGA AMIL ZAKAT NASIONAL NURUL HAYAT DI BOJONEGORO

sebesar $0,000<0,05$. Hasil ini menunjukkan bahwa semakin tinggi kinerja usaha yang dijalankan mustahik dengan produktivitas yang baik, maka semakin tinggi pula kesejahteraan yang diterima oleh mustahik.

\section{SIMPULAN DAN SARAN}

Simpulan penelitian sebagai berikut:

1. Zakat Produktif secara parsial berpengaruh positif dan signifikan terhadap kinerja mustahik diketahui bahsa nilai T-statistic sebesar 5,995 lebih besar dari nilai T tabel yaitu 1,96 dan nilai signifikasi sebesar $0,000<0,05$ dengan demikian dalam penelitian ini $\mathrm{Ha} 1$ diterima dan $\mathrm{Ha} \mathrm{O}$ ditolak

2. ZakatProduktif secara parsial berpengaruh positif dan signifikan terhadap kesejahteraan mustahik, diketahui bahwa nilai T-statistic sebesar $9,266>1,96$ dan nilai signifikasi $p$ value $0,000<0,05$ dengan demikian dalam penelitian ini $\mathrm{Ha} \mathrm{l}$ diterima dan $\mathrm{HO}$ ditolak.

3. Kinerja Usaha Mustahik secara parsial berpengaruh positif dan signifikan terhadap kesejahteraan ekonomi mustahik, diketahui bahwa nilai Tstatistic untuk variabel zakat produktif sebesar 8,412>1,96 dan nilai signifikansi $p$ value $0,000<0,05$ dengan demikian dalam penelitian ini Ha 1 diterima dan HOl ditolak.

\section{Saran}

1. Bagi Lembaga Amil Zakat Nurul Hayat Kabupaten Bojonegoro
Hendaknya Lembaga Amil Zakat Nurul Hayat Kabupaten Bojonegoro dalam meningkatkan kesejahteraan mustahik juga harus memiliki sasaran mustahik yang lebih luas dengan memberikan bantuan zakat produktif kepada mustahia yang berusia 40-50 tahun. Karena dalam usia tersebut banyak mustahiq yang memerlukan pengembangan modal usahanya.

2. Bagi Penelitian Selanjutnya

Keterbatasan penelitian ini, dikarenakan hanya menggunkan satu variabel independen saja dalam mengukur kesejahteraan ekonomi mustahik, sehingga penelitian ini mampu menjelaskan sebesar 28,9\% terhadap variabel kesejahteraan ekonomi mustahik, sedangkan $71,1 \%$ dipengaruhi atau dijelaskan oleh variabel lainnya yang tidak terdapat dalam penelitianini. Oleh sebab itu, untuk penelitian selanjutnya diharapkan untuk menambahkan variabel bebas, untuk mengukur sejauh mana penilaian terhadap kesejahteraan ekonomi mustahik.

\section{DAFTAR PUSTAKA}

Abdillah, W., \& Hartono, J. (2015).Partial Least Square (PLS): Alternatif Structural Equation Modeling (SEM) Dalam Penelitian Bisnis. Yogyakarta: Andi

Afzalurrahman. (2000). Muhammad Sebagai Seorang Pedagang. Jakarta: Yayasan Swarna Bhumy. 
Wafi, et al/Jurnal Ekonomi Syariah Teori dan Terapan Vol. 6 No. 7 Juli 2019: 1494-1508; PEMBERIAN ZAKAT PRODUKTIF UNTUK KINERJA MODAL USAH DAN KESEJAHTERAAN EKONOMI MUSTAHIK PADA LEMBAGA AMIL ZAKAT NASIONAL NURUL HAYAT DI BOJONEGORO

Akhiroh, M. (2018). Aanalisis Faktor-Fakyor Yang Mempengaruhi Kesejahteraan Mustahiq Dalam Pendayagunaan Zakat Produktif (Studi Kasus Badan Amil Zakat Nasional Kota Semarang dan Rumah Zakat Kota Semarang). Undergraduate thesis. Semarang: Universitas Wahid Hasyim.

Asnaini. (2008). Zakat Produktif dalam Perspektif Hukum Islam. Yogyakarta : Pustaka Pelajar.

Aziz, A.H. et al. (2012). Zakat dan Pemberdayaan. Surabaya:

Airlangga University Press.

Bojonegoroblok. (2018, 22 Desember) [online]. Data BPS, Angka Kemiskinan Bojonegoro Tiga Tahun Ini Turun. Diakses pada tanggal 2 Januari 2019dari

http://blokbojonegoro.com/2018/1 2/22/data-bps-angka-kemiskinanbojonegoro-tiga-tahun-ini-turun/.

Cahyadi, A.M. (2016). Analisis Pengaruh Zakat Produktif Terhadap Kesejahteraan Dengan Perkembangan Usaha Mikro sebagai Variabel Intervining (Studi Kasus Pada Badan Amil Nasional Daerah Istimewa Yogyakarta). Undergraduate thesis. Yogyakarta: Program Studi Hukum Islam UIN Sunan Kalijaga.

Cahyono, T. (2017). Statistik Uji Kolerasi. Purwokerto: Yayasan Sanitarian Banyumas.
Chapra, M. U. (2000). Sistem Moneter Islam. Jakarta: Gema Insani Press.

Farid, M. M (2005). Pajak Itu Zakat Uang Allah Untuk Kemaslahatan Rakyat. Bandung: Mizan Pustaka.

Farid, M., Sukarno, H., Puspitasari, N. (2015). Analisis Dampak Penyaluran Zakat Produktif Terhadap Keuntungan Usaha Mustahiq. Artikel IImiah Mahasiswa. Jember: Universitas Jember.

Hafidhuddin, D. (2002). Zakat Dalam Perekonomian Modern. Jakarta: Gema Insani.

Heriangingrum, S., Insani, D.T., Al-Faizin, W.A. (2018). Zakat: Concept and Implications To Social and Economic (Economic Tafsir Of AlTawbah:103). Jurnal of Islamic Monetary Economics and Finance. Vol. 04, No. 1, May 2018.

Jamal, R. ( 2015). Maqashid Al-Syari'ah dan Relevansinya Dalam Konteks Kekinian. Skripsi tidak diterbitkan. Manado:STAIN Manado.

Karimah, A. (2017). Efektivitas Pendayagunaan Zakat Produktif Pada Program Pemberdayaan Ekonomi Masyarakat (Studi Kasus Sejuta Berdaya LAZ Al-Azhar Peduli Ummat di Kelurahan Pisangan, Depok, Jawa Barat). Undergraduate thesis. Jakarta: Fakultas Ekonomi dan Bisnis Universitas UIN Syarif Hidayatullah.

Kasim., Budiman, A.M., \& Siswanto, E.I. (2014). Analisis Efektivitas Pendaya 
Wafi, et al/Jurnal Ekonomi Syariah Teori dan Terapan Vol. 6 No. 7 Juli 2019: 1494-1508; PEMBERIAN ZAKAT PRODUKTIF UNTUK KINERJA MODAL USAH DAN KESEJAHTERAAN EKONOMI MUSTAHIK PADA LEMBAGA AMIL ZAKAT NASIONAL NURUL HAYAT DI BOJONEGORO

gunaan Zakat Produktif Program Pemberdayaan Masyarakat di Wilayah Sukabumi (Studi Kasus: Kampung Ternak Dompet Dhuafa). Jurnal Ekonomi Dan Perbankan Syariah.

Kholiq, A. (2012). Pendayagunaan Zakat, Infaq, dan Sedekah Untuk Pemberdayaan Ekonomi Masyarakat Miskin di Kota Semarang. Vol. 6, No. 1:39-47.

Kuncoro, A.E., \&Riduwan. (2017). Cara Mudah Menggunakan dan Memaknai Path Analysis (Analisis Jalur). Bandung: Alfabeta.

Mahmudah, H. S., \& Ghoniyah, N. (2016) Model Pemberdayaan dan Peningkatan Kinerja Usaha Kecil Menegah (UKM). Semnas. Semarang: Fakultas Ekonomi Unissula.

Maulana, H. (2008). Analisa Distribusi Zakat Dalam Meningkatkan Kesejahteraan Mustahik (Studi Pada BAZ Kota Bekasi). Undergraduate thesis. Jakarta: Fakultas Syari'ah dan Hukum Universitas Islam Negeri Syarif Hidayatullah

Mauludi, A. (2015). Teknik Belajar Statistik 2. Jakarta: Alim Publishing.

Muda, I., \& Arfan, M. (2016). Pengaruh Jumlah Zakat Produktif, Umur Produktif, dan Lama Usaha Mustahik terhadap Produktifitas Usaha Mustahik. Jurnal IImiah Mahasiswa Ekonomi Akutansi (JIMEKA). Vol. 1, No. 1. 318-326.
Mutia, A., \& Zahara, E. A. (2009). Analisis Faktor-Faktor yang Mempengaruhi Kesejahteraan Ekonomi Mustahik Melalui Pemberdayaan Zakat (Studi Kasus Penyaluran Zakat Produktif/Modal Usaha pada BAZDA Kota Jambi). Jurnal Fakultas Syari'ah IAIN Sulthan Thaira Saifuddin Jambi. Vol. 25, No. 1, Juli 2009.

Nawawi, I. (2010). Budaya Organisasi Kepemimpinan dan Kinerja Organisasi.Sidoarjo: Mitra MediaNusantara.

Nidityo, G. H., \& Laila. N. (2014). Zakat Produktif Untuk Meningkatkan Kinerja Produksi, Motivasi dan Religiusitas Mustahiq. Jurnal Ekonomi dan Bisnis Univeritas Airlangga. Vol. 1, No. 9, September 2014.

Nugraha, B. (2017). Hubungan Persepi Peserta Tentang Program Life Skill Dengan Pemenuhan Kebutuhan Pokok di PKBM Al-Amin Desa Beusi Kecamatan Ligung Kabupaten Majalengka. Undergraduate thesis. Bandung: Universitas Pasundan.

Purbaya, G.A. (2015). Strategi Peningkatan Kesejahteraan Ekonomi Masyarakat Pengusaha Kerupuk dan Camilan Hasil Laut di Pantai Kenjeran Lama Surabaya.Undergraduate thesis.UIN SunanAmpel Surabaya.

$\begin{array}{cr}\text { (2016). Strategi } & \text { Peningkatan } \\ \text { Kesejahteraan } & \text { Ekonomi } \\ \text { Masyarakat:Kasus } & \text { Pengusaha }\end{array}$


Wafi, et al/Jurnal Ekonomi Syariah Teori dan Terapan Vol. 6 No. 7 Juli 2019: 1494-1508; PEMBERIAN ZAKAT PRODUKTIF UNTUK KINERJA MODAL USAH DAN KESEJAHTERAAN EKONOMI MUSTAHIK PADA LEMBAGA AMIL ZAKAT NASIONAL NURUL HAYAT DI BOJONEGORO

Krupuk dan Camilan Hasil Laut di Pantai Kenjeran Lama Surabaya. Jurnal Online UIN Ampel Surabaya. Vol. 1, No. 1, Desember 2016.

Oswari, T., Suhendra, S., Harmoni, A. (2008). Model Perilaku Penerimaan Teknologi Informasi: Pengaruh Variabel Prediktor, Moderating Effect, Dampak Penggunaan Teknologi Informasi Terhadap Produktivitas dan Kinerja Usaha Kecil. Seminar IImiah Nasional Komputer dan Sistem Intelijen. Depok: Universitas Gunadarma.

Ramli, R.M., \& Nurbismi. (2018 ). Pengaruh Zakat Produktif, Pendapatan, dan Kinerja Amil Terhadap Kemiskinan Amil Mustahik di Kota Banda Aceh. Jurnal Ekonomi dan Manejemen Teknologi. Vol. 2, No. 2:55-109.

Ridwan, M. (2005). Zakat dan Kemiskinan Instrumen Pemberdayaan Ekonomi Umat. Yogyakarta: UII Press.

Rusli, Hamzah, B. A., \& Syahnur, S. (2013) Analisis Dampak Pemberian Modal Zakat Produktif Terhadapat Pengentasan Kemiskinan di Kabupaten Aceh Utara. Jurnal IImu Ekonomi Pasca Sarjana Universitas Syiah Kuala. Vol.1, No. 1, 2013.

Sartika, M. (2008). Pengaruh Pendayagunaan Zalat Produktif Terhadap Pemberdayaan Mustahiq pada LAZ Yayasan Solo Peduli Surakarta. Vol. II, No. 1, Juli 2008.
Statistik, P. B. (2018, 16 Juli) [on-line]. Persentase Penduduk Miskin Maret 2018 Turun Menjadi 9,82\%. Diakses pada tanggal 2 Januari 2019 dari https://www.bps.go.id/pressrelease /2018/07/16/1483/persentasependuduk-miskin-maret-2018-turunmenjadi-9-82-persen.html.

Sugiyono. (2017). Metode Penelitian Pendidikan Pendekatan Kuantitatif, Kualitatif dan R\&D. Bandung: Alfabeta.

Supranto, J. (2003). Metode Riset Aplikasi Dalam Pemasaran. Edisi Revisi Ketujuh.Yogyakarta: Rineka Cipta.

Suratno. (2017). Pengaruh Pendayagunaan Zakat Produktif Terhadap Pemberdayaan Mustahiq (Studi Pada Lembaga Amil Zakat DPUDT Bandar Lampung). Undergraduate thesis. Fakultas Ekonomi dan Bisnis Islam UIN Raden Intan Lampung.

Syarifuddin. (2014). Pengaruh dan Manfaat Zakat Infaq dan Shadaqah Terhadap Produktivitas Usaha dan Kinerja Usaha Serta Kesejahteraan Mustahiq Pada Badan Amil Zakat Daerah Kabupaten/Kota di Provinsi Kalimantan Timur.Thesis. Surabaya: Universitas Airlangga.

Tim Kajian Keislaman Nurul IImi. (2012). BukU Induk Terlengkap Agama Islam. Yogyakarta: Citra Risalah.

Tho'in, M. (2017). Pembiayaan Pendidikan Melalui Sektor Zakat. Jurnal Ekonomi Syariah. Vol. 9, No. 2, 2017. 
Uswatun, H. (2016). Efektivitas Distribusi Zajat

Baznas Sumsel Dalam

Meningkatkan Kesejahteraan

Mustahik Di Pasar Kuto Periode

2011-2013. Undergraduate thesis.

Palembang: UIN Raden Fatah.

Wahid, H., Ahmad,S., \& Kader, A.R. (2009).

Pengagihan Zakat oleh Institusi Zakat kepada Lapan Asnaf: Kajian di Malaysia. Working Paper disampaikan dalam Seminar Kebangsaan Ekonomi Islam 2008/09 pada 10-11 Februari 2009 di APIUM Malaysia.

Waluyo, A. (2018). Ekonomi Islam dalam Bingkai MaqashidAsy-Syari'ah. Yogyakarta: Ekuilibria.

Winoto, N. G. (2011). Pengaruh Dana Zakat Produktif Terhadap Keuntungan Usaha Mustahik Penerima Zakat (Studi Kasus BAZ Kota Semarang). Undergraduate thesis. Semarang: Universitas Diponegoro

Yuliani, I. (2017). Pengaruh Zakat Infaq dan Shadaqah (ZIS) Produktif Terhadap Pertumbuhan Usaha Mikro dan Penyerapan Tenaga Kerja Serta Kesejahteraan Mutahik (Studi Pada BAZNAS Daerah Istimewa Yogyakarta). Undergraduate thesis. Yogyakarta: Fakultas Ekonomi dan Bisnis Islam Universitas Islam Negeri Sunan Kalijaga Yogyakarta. 